\begin{tabular}{c|c}
$\begin{array}{c}\text { ADVANCE RESEARCH JOURNAL OF SOCIAL SCIENCE } \\
\text { REVIEw }\end{array}$ & $\begin{array}{c}\text { Volume } 8 \mid \text { Issue } 2 \mid \text { December, 2017 |360-364 } \\
\text { e e ISSN-2231-6418 }\end{array}$ \\
DOI: 10.15740/HAS/ARJSS/8.2/360-364 & Visit us : www.researchjournal.co.in
\end{tabular}

\title{
Interpreting non-verbal behaviour during forensic assessment interview test (FAINT) and polygraph techniques
}

Nilesh Anand Bharne*, S.L. Vaya ${ }^{1}$ and Asha Srivastava ${ }^{2}$

Raksha Shakti University, Ahmedabad, DEHRADUN (UTTARAKHAND) INDIA

${ }^{1}$ Institute of Research and Development, Raksha Shakti University, AHMEDABAD (GUJARAT) INDIA

${ }^{2}$ Forensic Psychology Division, Central Forensic Science Laboratory, NEW DELHI (INDIA)

\section{ARTICLE INFO :}

Received : 03.07 .2017

Accepted : 22.11 .2017

\section{KEY WORDS :}

Non-verbal behaviour, FAINT,

Polygraph, Psycho- Somatic

HOW TO CITE THIS ARTICLE :

Bharne, Nilesh Anand, Vaya, S.L. and Srivastava, Asha (2017). Interpreting nonverbal behaviour during forensic assessment interview test (FAINT) and polygraph techniques. Adv. Res. J. Soc. Sci., 8 (2) : 360-364, DOI: 10.15740/ HAS/ARJSS/8.2/360-364.

*Author for correspondence

\section{ABSTRACT}

While delivering FAINT Test and Polygraph test to the suspected criminals in Crime Cases, we are significant changes in their non-verbal behaviour. In Both the test truthful person has normal indicator/score, same as the normal person. While the deceptive person show significant variation in their non-verbal behaviour in both the test. 